\title{
Electrospun Nanomaterials Implementing Antibacterial Inorganic Nanophases
}

\author{
Nicoletta Ditaranto ${ }^{1}$ (D), Francesco Basoli ${ }^{2}$, Marcella Trombetta ${ }^{2}$, Nicola Cioffi ${ }^{1, *}$ (D) \\ and Alberto Rainer ${ }^{2, *}$ \\ 1 Dipartimento di Chimica, Università degli Studi di Bari “Aldo Moro”, via Orabona 4, 70125 Bari, Italy; \\ nicoletta.ditaranto@uniba.it \\ 2 Dipartimento di Ingegneria, Università Campus Bio-Medico di Roma, Via Álvaro del Portillo 21, \\ 00128 Roma, Italy; f.basoli@unicampus.it (F.B.); m.trombetta@unicampus.it (M.T.) \\ * Correspondence: nicola.cioffi@uniba.it (N.C.); a.rainer@unicampus.it (A.R.); \\ Tel.: +39-08-05-442020 (N.C.); +39-06-22-5419214 (A.R.)
}

Received: 2 August 2018; Accepted: 7 September 2018; Published: 13 September 2018

\begin{abstract}
Electrospinning is a versatile, simple, and low cost process for the controlled production of fibers. In recent years, its application to the development of multifunctional materials has encountered increasing success. In this paper, we briefly overview the general aspects of electrospinning and then we focus on the implementation of inorganic nanoantimicrobials, e.g., nanosized antimicrobial agents in electrospun fibers. The most relevant characteristics sought in nanoantimicrobials supported on (or dispersed into) polymeric materials are concisely discussed as well. The interesting literature issued in the last decade in the field of antimicrobial electrospun nanomaterials is critically described. A classification of the most relevant studies as a function of the different approaches chosen for incorporating nanoantimicrobials in the final material is also provided.
\end{abstract}

Keywords: Electrospinning; antimicrobial; metal nanoparticles; nanofibers

\section{Electrospinning: Generalities}

Electrospinning is an easy fabrication method in which electrostatic forces are used to produce fine fibers. For its versatility, simplicity, and low cost, electrospinning has attracted the interest of many researchers fascinated by the possibility to fabricate fibers with both micro and nano-sized structural features by finely tuning process parameters. For these reasons, electrospinning has been extensively reviewed with respect to its setup, applications, advantages, and prospective developments [1,2]. Even though the origin of electrospinning can be traced back to the first years of the twentieth century [1,3-7], the term "electrospinning" is rather recent. In fact, it was used for the first time in 1995 by R.H. Reneker and coworkers in two different scientific articles [8,9].

The electrospinning fabrication process can be briefly summarized as follows. A high voltage (generally in the order of a few tens of kilovolts) is applied between an extrusion system (i.e., a needle or spinneret) and a collector. A polymeric solution is fed at a set flow rate to the spinneret where, under the force exerted $b$ the electric field, it starts elongating forming a characteristic cone-shaped tip (Taylor's cone) [10,11]. When surface tension is overcome by electrostatic forces, a jet of liquid is ejected from the Taylor cone, and reaches the collector in the form of a solid nonwoven web, with solvent evaporating during flight [12]. Lateral instabilities in the charged travelling jet result in a whipping motion that further contributes to fiber elongation [13] (see Figure 1). A thorough analysis of the physical phenomena behind the electrospinning process and a detailed description of the main experimental setups can be found in Reference [14]. 


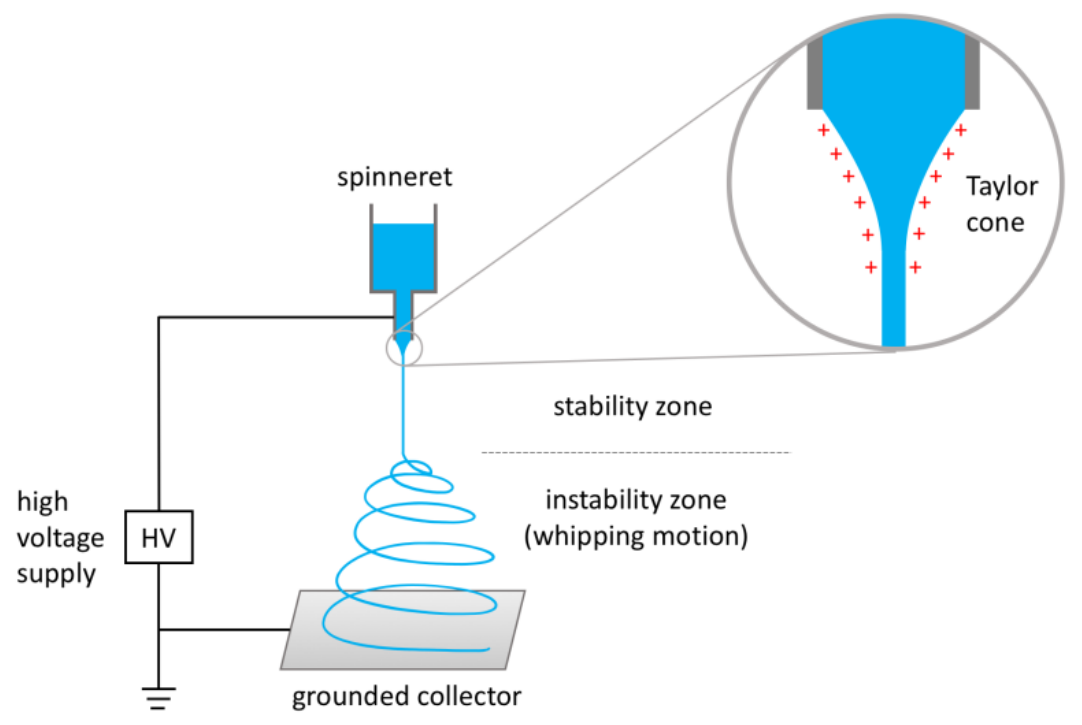

Figure 1. A typical electrospinning set-up, comprising: (i) A spinneret containing the polymeric solution; (ii) a DC high voltage supply; and (iii) a grounded collector. A charged jet of polymer solution is extracted from the spinneret tip (with a typical cone shape, in the inset) and reaches the collector with a typical whipping motion.

The electrospinning process is affected by three classes of parameters, including solution properties (e.g., concentration, viscosity, surface tension, conductivity, and solvent vapor pressure), process parameters (e.g., solution feed rate, applied voltage, nozzle-to-collector distance), and ambient parameters (e.g., humidity and temperature). Seyedmahmoud et al. have demonstrated the feasibility of applying statistical methods to gain a quantitative and systematic insight about the effects of process parameters on the resulting fiber properties $[15,16]$.

Electrospinning has been the subject of many different setup modifications that have been implemented over the years to accommodate different application needs. In fact, besides the more conventional randomly oriented fiber mats, a variety of morphologies and structures can be achieved by purposely changing the electrospinning conditions and by modifying the setup (e.g., the spinneret and the collector, among others) [17].

Mat morphology (i.e., fiber alignment and pattern) can be influenced by the collector geometry. In order to produce a randomly oriented non-woven mat, a static planar target is the conventional choice, whereas to obtain aligned fibers, collection is performed around a rotating cylindrical target [18, 19]. In different designs, a series of parallel electrodes have been used to generate aligned fibers $[20,21]$. For more specific applications, collectors have been designed with customized geometries to obtain specific orientations or patterns, such as a knife-edge rotating disk to collect highly aligned fibers [22], or the use of grid-shaped collectors to create patterned nanofibrous mats [23].

The spinneret was also the subject of various modifications targeting specific applications. One of the major advances in electrospinning is represented by the introduction of the coaxial configuration in 2003 [24], enabling the production of core-shell microarchitectures with compartmented properties. Further incremental improvements (i.e., triaxial spinneret) have led to the fabrication of multilayered fiber structures [25] with the possibility to independently tune thickness, degradation rate, and diffusion properties of each layer for advanced drug delivery applications.

In 2008, Liu et al. [26] demonstrated the possibility to fabricate electrospun nano-fibers by a needless setup. Using an aerated polymer solution, they managed to produce continuous and uniform nanofibers. In fact, insufflation of gas inside a vessel containing the polymer solution led to the formation of bubbles on the solution surface, that could give rise to the extraction of nanofibers upon the application of a potential. The key advantages of this novel design, called bubble electrospinning, is represented by the easiness to overcome the surface tension of the small bubbles, and the scalability 
of the process, which has the potential for the mass-production of nanofibers. Moreover, different from classical electrospinning, in which spinnability mainly depends on the solution properties, in bubble-electrospinning it mainly depends on the size of the bubbles [27].

Electrospun meshes are characterized by high surface-to-volume ratio, dimensions ranging from tens of nanometers to micrometers, high porosity, and variable pore size distribution, showing morphological similarities to the natural extracellular matrix (ECM). Hence, one of the main applications for electrospun fibers has been as scaffolds for tissue engineering.

Additionally, the possibility to modify fiber surface and the ease of incorporating molecules or nanoparticles of interest in the solution to be electrospun further enhanced their range of application, including drug delivery systems [28-30], water treatment [31,32], energy conversion and storage [33,34], biosensing devices [35], gas sensors [36,37], electronics [38], as sorbents in microextraction techniques [39], as chromatographic phases [40], as separators, concentrators, or mixers in microfluidic systems [41-43].

\section{Nanoantimicrobials}

In the last two decades, antimicrobial nanomaterials—concisely addressed as nanoantimicrobials (NAMs) - have risen a tremendous interest in both fundamental and application-oriented research [44]. The continuous search for new agents capable of preventing the growth of pathogens and other undesired microorganisms, urged by the increased worldwide concern about antimicrobial resistance [45], has stimulated a massive development of new materials and processes implementing NAMs [46-48]. This class of bioactive materials is being used in formulations, technological solutions, and commercial products, which are available for the consumer [49].

Among the different inorganic NAMs, nanomaterials composed of transition metals such as Ag, $\mathrm{Cu}, \mathrm{Zn}$, and their oxides are the most diffused, since they provide a wide-range biocidal activity, and on the other side, they are well tolerated by human beings at concentration levels that are effective already towards the growth of several microorganisms [48]. A comprehensive overview on real-life applications of NAMs is provided by References [44,50-57]. Silver-based NAMs are definitively the most investigated. This is due to the concurrence of different causes. Firstly, silver provides an efficient biocidal effect toward a broad range of microorganisms; and secondly, the general lack of solubility that silver salts and compounds show in several aqueous media (for instance chloride-containing fluids) intrinsically buffers the concentration of bioactive ionic species that can be released by Ag nanophases, thus prolonging their biocidal effects. Finally, the number of synthetic routes to coinage metal nanophases is enormous; this guarantees an easy access to nanosilver biocidal agents, and supports the production of an almost infinite number of goods implementing Ag-NAMs. Such a wide and indiscriminate diffusion of active nanomaterials is rising an increasing concern about their environmental toxicity, and particularly the risks related to the NAMs action towards non-target organisms [58]. In this respect, engineered nano-sized agents which are protected, encapsulated, or in any case, prevented from direct release into contact media are by far the most interesting NAMs. Since 2004 [59], we proposed the inclusion of copper nanoparticles into water insoluble polymers as one of the best routes to gain a controlled bioactivity from NAMs. In other words, NAMs should be better used as nano-reservoirs in a composite material, providing a tunable release of bioactive species (such as metal ions), rather than being just added (as entire nanophases) to the system where the biocidal effect is sought. The most important requisite for the resulting material is to protect the NAMs from being directly released into the contact solution, but on the other side, the inorganic nanophases has to retain part of its reactivity, in order to undergo the corrosion and ionic release processes, which support the final biocidal effects [60].

More recently, we have further explored this approach, combining microscopy and analytical spectroscopy techniques, demonstrating that a proper NAM adhesion or encapsulation in polymer coatings prevents the release of entire nanoparticles [61], paving the way to the development of efficient and safe NAMs [62]. 
With this in mind, we believe that the combination of NAMs with innovative polymer synthesis and/or processing technologies, such as the electrospinning technique, affording a high level of morphological and composition control over the resulting material, will represent a proper solution for a further step in the diffusion and exploitation of these agents.

\section{Electrospun (Nano)Materials Implementing Antibacterial Properties}

The advantage of using antimicrobial polymers to fight the increasing resistance against classical antibiotics arises from the possibility of synergistically combining these materials and applying them in different physical forms (e.g., coatings, films, emulsions and fibers). Polymer fibers produced via electrospinning are among the most efficient and cost effective systems for two main reasons: In the first place, because of their huge surface area-to-volume ratio; and secondly, the polymers can be implemented with antimicrobial functionalities before or after electrospinning. This provides the opportunity to design and modify the fibers in the smartest way to specifically target different types of microorganisms.

Antimicrobial polymers can be classified into two categories. The first one includes all those polymers with inherent antimicrobial or antiseptic properties, that can be directly applied or used in a variety of substrates, namely textiles, metal materials or plastics ones. The second category contains inert polymers incorporating additional antimicrobial phases/agents that are released over time.

The first class comprises natural and synthetic polymers, including polypeptides. Antimicrobial peptides are naturally associated to the defense system of microorganisms and humans [63], and are generally cationic species with an overall net positive charge. Based on those structures, synthetic amphiphilic polymers have been designed to mimic the antimicrobial peptides [64,65]. While many antimicrobial peptides have been described, their large-scale production is expensive, their in vivo stability is generally poor and relatively little investigated [66,67].

Electrospun nanofibrous membranes of natural polymers have recently drawn much attention as novel materials in biomedical applications, such as wound dressing, tissue engineering, and drug delivery. While the use of bio-based materials as precursors for electrospinning seemed to be an excellent solution to address all the raised concerns, many difficulties arose on the actual practical side. In fact, natural polymers are usually difficult to be electrospun, therefore the starting solution is frequently composed by a synthetic polymer in blend with the natural one. Another possible approach is to chemically modify the natural polymer, chitosan processing represents a classic example of this approach. Chitosan is an inherently antimicrobial natural polymer being highly active against both gram-positive and gram-negative bacteria. Thus, it would be an excellent candidate for the production of antimicrobial nanofibers [68]. Anyhow, pure chitosan cannot be merely electrospun into nanofibers, and this lead to the need of blending chitosan into the starting solution with other polymers (e.g., polyethylene oxide, polyvinyl alcohol, polycaprolactone) even though this dilution could lead to lowering the biocidal properties of the as made nanofibrous membranes. An interesting overview of different natural electrospun nanofibers for antibacterial uses, including a useful list of pure polymers and their blends successfully processed by electrospinning, is given by Vineis et al. and Bshena et al. $[69,70]$.

The second class of antimicrobial nanofibers is by far the most investigated, since different active agents as well as different strategies have been explored. Most commonly, biocides (e.g., antibiotics, ammonium salts, cyclodextrins, chlorhexidine, metal, or metal oxide nanoparticles, etc.) are attached to or encapsulated into supporting fibers, by means of different preparation approaches. The most straightforward one consists in anchoring the active agent onto the surface of pre-synthesized fibers. This approach, however, provides little control over the release rate, that is usually characterized by a burst. Alternatively, the active material can be encapsulated inside the fiber either by blending the active agent in the polymer solution before electrospinning or by firstly encapsulating the active agent into nanostructures to be dispersed in the electrospinning solution. Additionally, precursor compounds can be blended in the solution to be electrospun, and conversion to their active form 
can be performed as a post-electrospinning treatment. These approaches are effective in providing a sustained release of the active agent, regulated by its diffusion through the polymer matrix, by the degradation of the matrix, or by a combination thereof. More sophisticated approaches also foresee the use of a multi-axial electrospinning setup, in order to confine the active agent in the core of the obtained fibers, enhancing the control over the achievable release profiles (see Figure 2).

Many typologies of antibacterial nanofibers have been produced by the electrospinning technique, based on the incorporation of different biocides, as extensively reviewed in Reference [71], where a very comprehensive explanatory table is reported. As meaningful examples, we could focus on antibiotics incorporation (numerous hydrophilic and hydrophobic antibiotics have been used) [71] and cyclodextrines inclusion [72-75] into a polymeric solution. Attention has to be taken to the drug concentration, as an excess will probably lead to changes to polymer electrospinnability, and as a consequence, on fibers morphology, due to changes to solution properties as conductivity, viscosity, and surface tension.

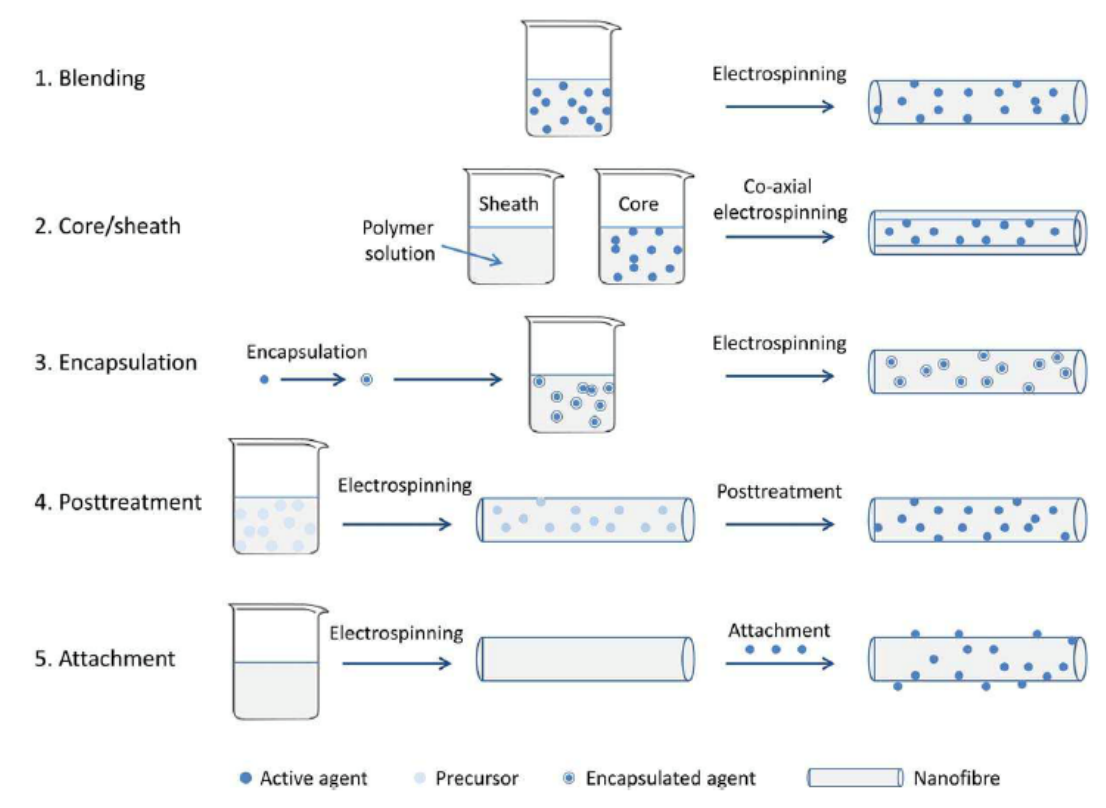

Figure 2. Various methods of incorporating biocides into electrospun nanofibers. (1) blending/ dispersion of the active agent in the polymer solution prior to electrospinning; (2) confinement of the active agent in the core of the fiber through co-axial electrospinning; (3) encapsulation/adsorption of the active agent in nanostructures before dispersion in the electrospinning solution; (4) conversion of a precursor to active agent in the nanofibers after electrospinning; and (5) attachment of the active agent onto the nanofibers after electrospinning. Reprinted from Reference [71], Copyright 2014, with permission from John Wiley and sons.

Another relevant drawback comes from the burst release associated to the loading of high drug amounts. Indeed, as soon as fibers are submerged into an aqueous solution, antibiotics will tend to leach out rapidly. This behavior provokes a reduced functionality of the nanofiber membrane against bacteria by releasing all the antibiotics in a very short time frame without guaranteeing a prolonged coverage period. To avoid burst release, different set-ups have been used: Coaxial electrospinning technique allows to create a polymer (e.g., polycaprolactone [76] poly(lactic-co-glycolic acid) [77], poly(lactic acid) [78], poly(methyl methacrylate)/nylon [79], and poly(L-lactide-co-caprolactone) [80]) sheath that encapsulate the antibiotic (e.g., gentamycin, ampicillin, tetracycline hydrochloride) component into the core section of the nanofibers. Another common approach for a sustained release of the antibiotics is to adsorb or encapsulate the drug in a nanostructure such as hydroxyapatite nanoparticles before dispersing it in the polymer solution [81-83]. This approach does not allow a high drug payload, but still provides a sufficient antibacterial activity. Among the others, potent antimicrobial materials 
that have been investigated in conjunction with polymers are the quaternary ammonium salts (QACs) and N-substituted halamines [84]. The strategy of preparing antimicrobial polymers based on QACs is very attractive, because tertiary or/and secondary amino groups provide convenient reactive moieties to be properly modified.

One of the approaches is to permanently attach the active QACs agents by means of coupling agents, such as alkoxysilanes, to a variety of different substrates through covalent interactions [85-88]. Besides, other methods include the use of ammonium salts derivatives as monomers in a quaternization reaction or simply adding a mixture of them to different polymer solutions. A comprehensive review by Jaeger et al. [89] discussed the multiple synthetic routes of various charged polymer systems that have quaternary ammonium moieties.

Recently, some concerns have been raised over possible drawbacks in the use of nanoparticles/nanomaterials (including nanosized antimicrobial agents) and synthetic antibiotics. It has been pointed out that they could be of some hazard to the environment, could have collateral effects on human health, and/or could possibly create bacterial resistance issues. On the other hand, is strictly demanding an effective prevention of infections caused by biofilm-forming pathogens. To address those issues, many engineered nanofibrous membranes containing metal and/or metal oxides nanoparticles have been proposed, mainly based on the use of silver, copper, and zinc, thanks to their well-established disinfectant properties. It is generally accepted that the effect of metals in a nanoparticles form is due both to the release of metal ions and to the direct contact with the bacterial cell membranes; anyhow, metal nanoparticles present the advantage of acting as active reservoirs. In this context, the decreased amount of metal, combined with the encapsulation/stabilization into electrospun fibers, is expected to produce environmentally sustainable materials, nontoxic for human health, with reduced nanotoxicology issues [90].

\section{Inclusion of Metal Nanophases as Biocides}

Silver has long been known as an effective antibacterial agent and it has been used in various applications thanks to its chemical versatility. Copper and copper oxide, as well, possess antimicrobial properties that have been known for centuries on the macroscale [91]. With the progress of technological applications, the cost control remains a key factor when considering the scale up and the wide range of applications on a large scale. For this reason, cheaper metals (copper, zinc, iron, titanium) have increasingly become the selected metals to confer antimicrobial properties, in place of or in combination with silver. Among others, electrospun nanofiber materials have been produced incorporating metal nanostructures by different strategies and with various polymers, according to the final application.

One of the widespread methods consists of a salt solution mixed with a polymer one to obtain the final electrospinning mixture (blending). In this conditions the metal species are stabilized in the nanoparticle form by means of the polymer itself, acting both as reductant and as capping agent. Following this approach, Quiròs at al [92] obtained Ag-, Zn- and Cu-poly(vinylpyrrolidone) (PVP) composite mats at different copper loadings, with good antibacterial performances against $E$. coli and S. aureus.

The same approach has been reported using poly(vinyl alcohol) (PVA), as one of the most used and desirable material for biomedical applications. Its highly favorable properties, such as biocompatibility, nontoxicity, and bioadhesive characteristics make it a good candidate to be modified with biocidal nanophases inclusion. As the incorporation of $\mathrm{Ag}$ salts into easily electrospinnable polymers matrices produces an even particles distribution, many papers have been published on the AgNPs/PVA system [93-95]. Typically, the polymer acts as stabilizer of the nanocomposite fibers and also has good reductant capabilities to yield Ag nanoparticles directly formed during the electrospinning process [96]. In some cases, post-treatment processes are required, like adding a second reductant [97] or a combination of UV irradiation and/or heat treatment/calcination $[98,99]$. This approach could be also beneficial from the application point of view. For instance, Celebioglu et al. [97] reported on the influence of AgNPs size and/or a second component on the antimicrobial effect (see Figure 3). 
While Jin et al. [96] studied how different reducing conditions can affect the morphology of Ag-PVA nanofibers (Figure 4).

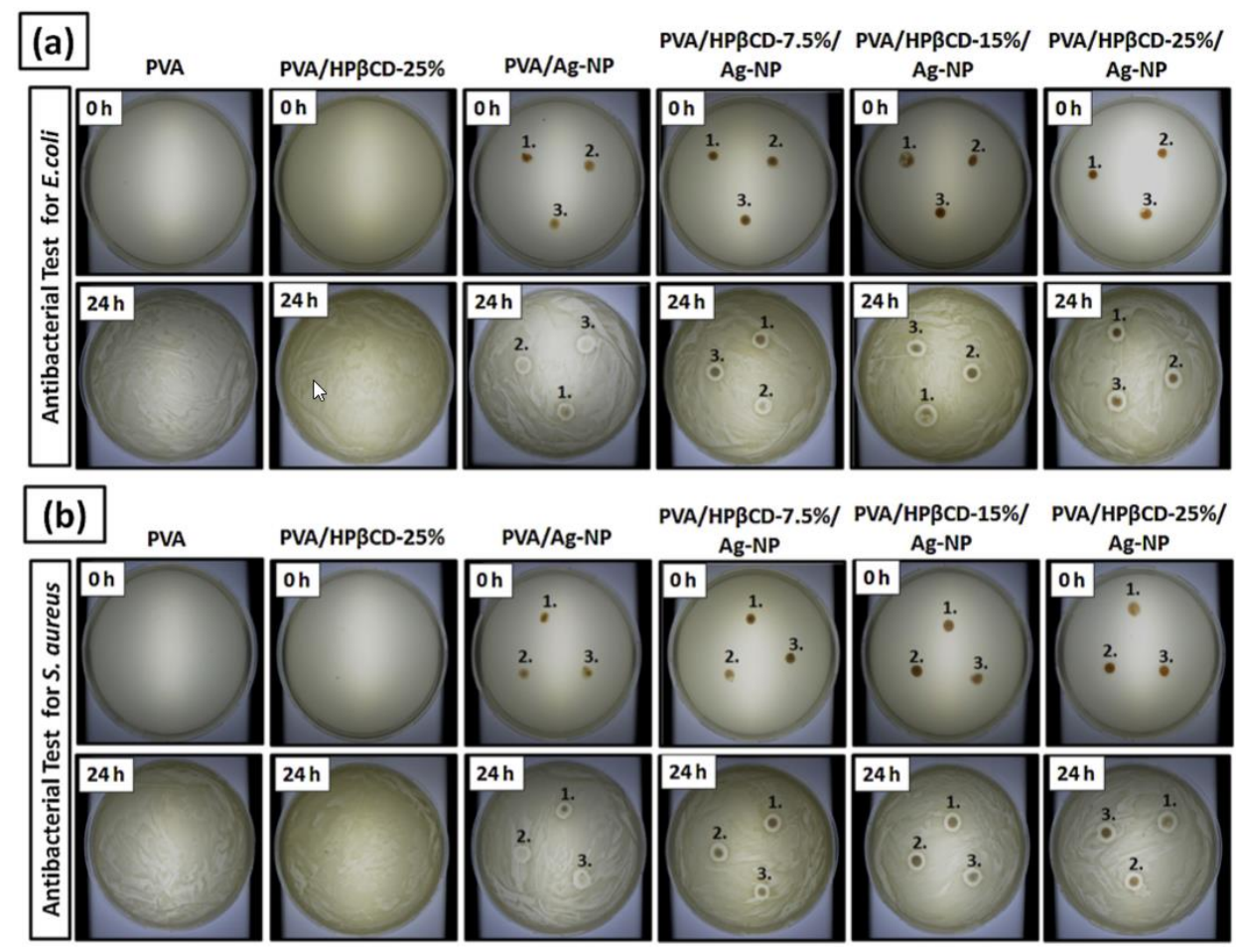

Figure 3. The photographs of antibacterial testing of nanofibrous mats that were performed against (a) E. coli and (b) S. aureus. Reprinted from [97], Copyright 2014, with permission from Elsevier.
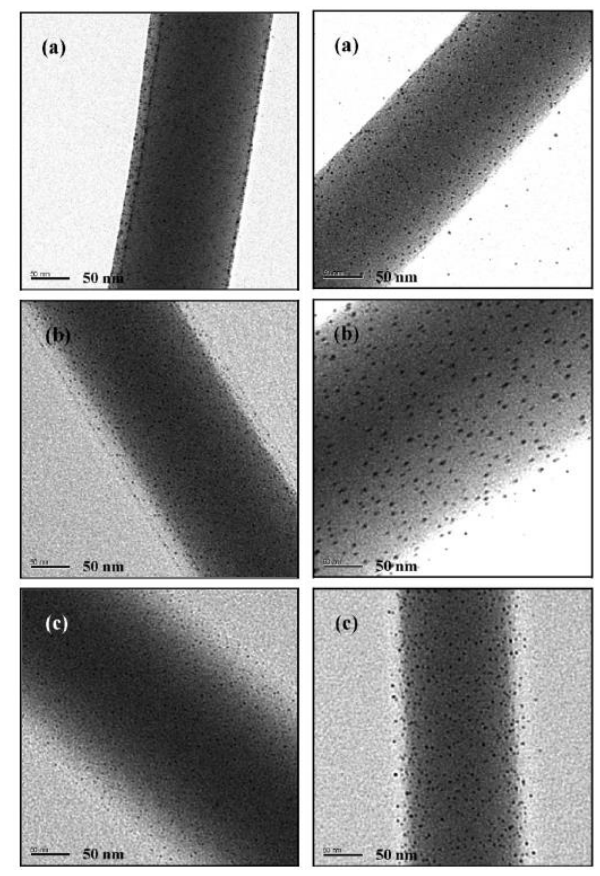

Figure 4. On the (left): TEM of PVA nanofibers electrospun from $12 \mathrm{wt} \%$ PVA solutions containing $1 \mathrm{wt} \%$ of $\mathrm{AgNO}_{3}$ : (a) Not refluxed, (b) refluxed at $80^{\circ} \mathrm{C}$ for $1 \mathrm{~h}$, and (c) refluxed at $80^{\circ} \mathrm{C}$ for $2 \mathrm{~h}$. On the (right): TEM of PVA (polyvinyl alcohol) nanofibers elect rospun from $12 \mathrm{wt} \%$ PVA solutions containing $1 \mathrm{wt} \%$ of $\mathrm{AgNO}_{3}$ after being annealed at (a) $50{ }^{\circ} \mathrm{C}$, (b) $80{ }^{\circ} \mathrm{C}$, and (c) $110{ }^{\circ} \mathrm{C}$ for $14 \mathrm{~h}$. Reprinted from [96], Copyright 2007, with permission from Elsevier. 
Electrospun Cu-PVA fibers have been produced in conjunction with $\mathrm{CuCl}_{2}$ [100] or copper acetate [101] to obtain PVA-protected copper nanoparticles. Additionally, mixed metal nanostructures have been produced, like $\mathrm{CuO}-\mathrm{ZnO}$, and have been included in PVA. The combination of two metals was demonstrated to be effective as enhanced adsorption and antimicrobial efficiency were obtained with these nanocomposite fibers [102]. Along with the antimicrobial results, the authors also proposed a mechanism responsible for the bactericidal action of those nanofibers (see Figure 5).
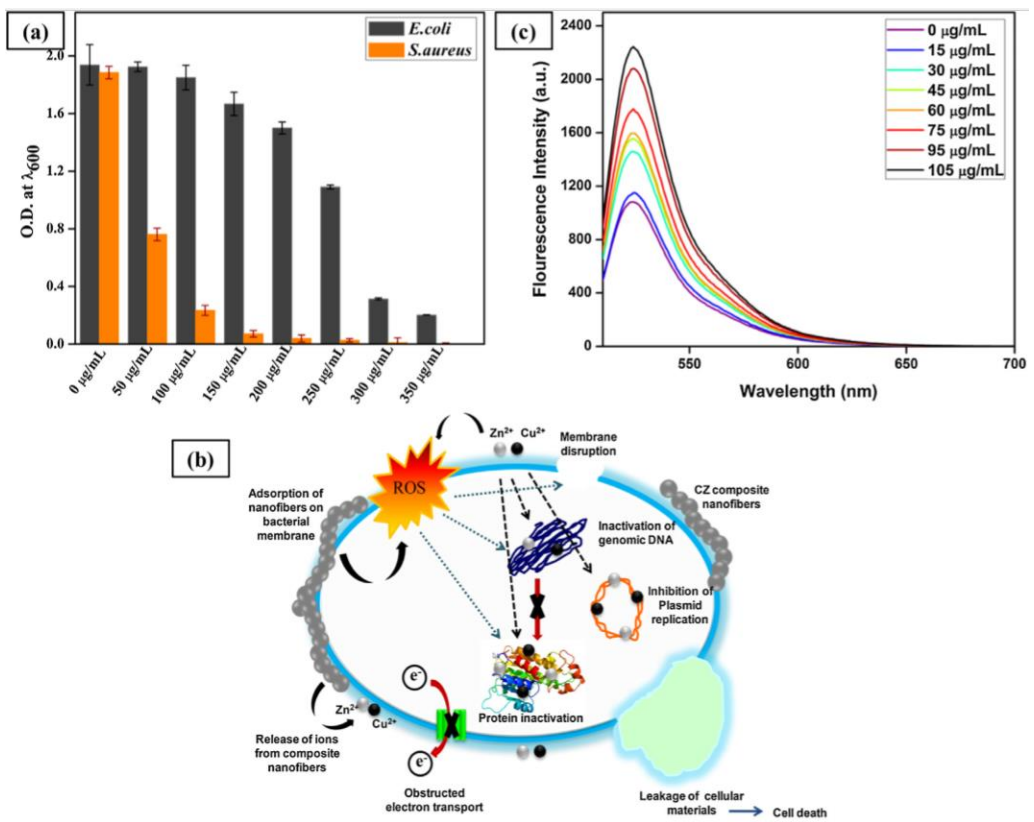

Figure 5. (a) Comparative plot representing the antibacterial activity of $\mathrm{CuO}-\mathrm{ZnO}(\mathrm{CZ})$ loaded nanofibers with different concentrations against GFP-E. coli (G-) and S. aureus (G+); (b) Proposed mechanism of bactericidal action $\mathrm{CZ}$ nanofibers; and (c) Fluorescence spectra depicting the ROS generation with different concentrations of CZ nanofibers. Reprinted from [102], Copyright 2017, with permission from Elsevier.

One of the major applications for electrospun fibers has long been in the filtration field and polyacrylonitrile (PAN) has been the most used, due to its high mechanical strength and chemical stability. One of the drawbacks in the filtration process is the rapid fouling by bacteria, negatively affecting the permeability and the throughput of the membrane. Moreover, PAN or composite cellulose/PAN fibers are widely employed in biomedical devices, where the bacterial control is an issue. In this respect, CuNPs and AgNPs may add a clear benefit when embedded in electrospun PAN and cellulose fibers. Additionally, in this case, the blending approach is the most investigated; silver and copper salts [103-105], or preformed $\mathrm{ZnO}-\mathrm{CuO}-\mathrm{NPs}$ [106], are included in the electrospinning solution. An interesting alternative is represented by the cellulose nanofibers, because the high number of -OH groups offers a location for fibers functionalization, thus regulating the nanophases upload and their release. Gouda et al. [107] published a comprehensive paper about carboxymethyl cellulose functionalized with copper, iron, and zinc NPs. They reported on the different morphology according to the different MeNPs (Figure 6), along with composite nanofibers release properties and their excellent antibacterial activity. 


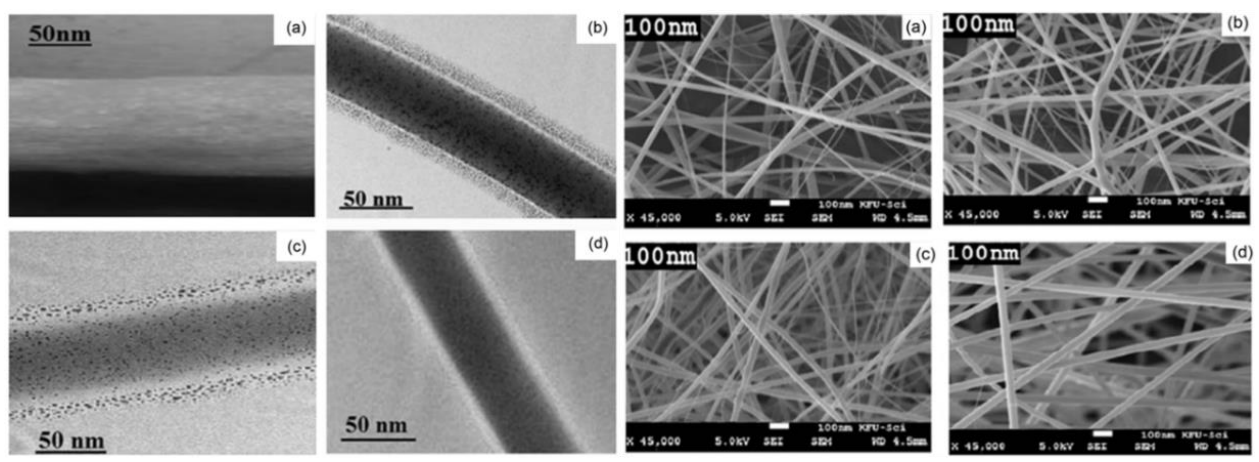

Figure 6. On the (left): TEM images of CMC electrospun nanofiber (a) and CMC-MNPs electrospun nanofibers CuNPs (b), FeNPs (c) and ZnNPs (d). On the (right): SEM images of CMC electrospun nanofiber (a) and CMC-MNPs electrospun nanofibers CuNPs (b), FeNPs (c) and ZnNPs (d). Reprinted by permission from [107], Springer Nature, Copyright 2017.

The attachment and core-sheath preparation methods are far less common and usually involve a two or three-step procedure. Nevertheless, they provide electrospun nanofibers with worthy performance as antimicrobial materials. In particular, when applications involve coatings [108] or barrier membranes [109], those methods offer good results. Moreover, the multi-step procedure offers the possibility to tune the materials properties and morphology, by acting on post-synthesis different parameters. Shi at al. [108] reported on Ag-PAN nanofibers obtained soaking electrospun fibers into silver nitrate solution, and were subsequently performing a reduction reaction. In Figure 7 the SEM characterization of those fibers is reported, where it is evident that the influence of silver salt concentration and reaction time on the adsorption effect and crystallization ability of silver ions. Then, the subsequent silver reduction step is a further independent parameter.

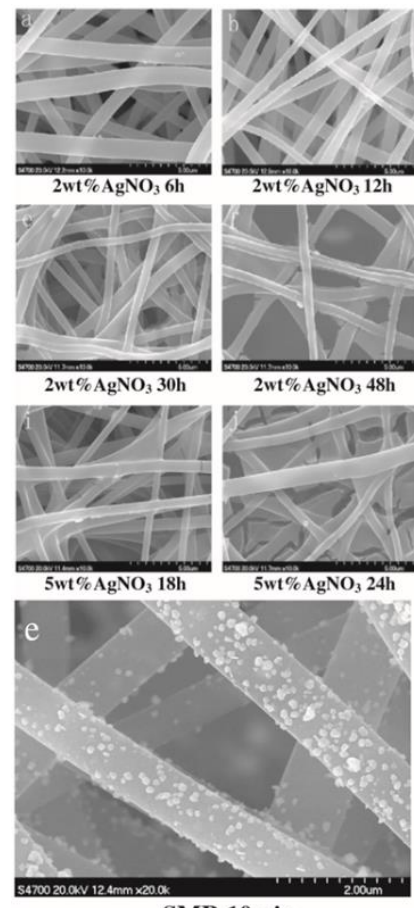

SMR 10min
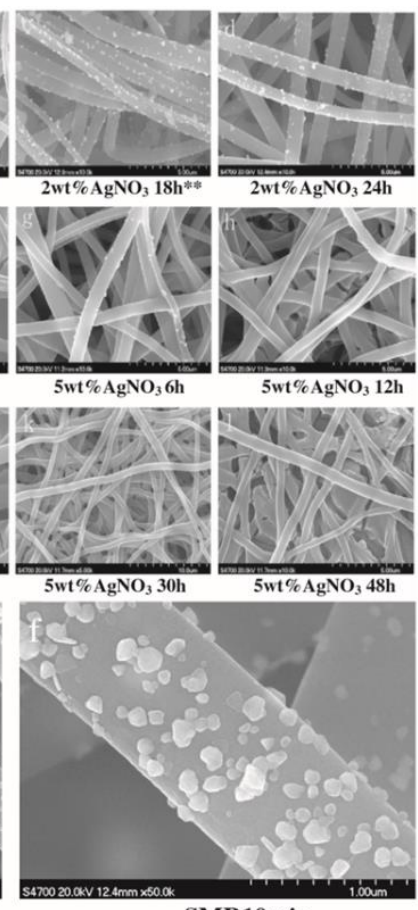

SMR10min

Figure 7. SEM images of pretreating PAN (polyacrylonitrile) nanofibers in $\mathrm{Ag} \mathrm{NO}_{3}$ solution at different soaking times, different concentrations, and different reduction reaction time. Reprinted from [108], Copyright 2015, with permission from Elsevier. 
An increased stabilization of the nanophases into the membranes is always beneficial and could be obtained by means of encapsulation approach, in order to avoid loosely attached nanoparticles to be dispersed in the environment. Few papers have been published so far following this method, which allows also a controlled release of metal species [110,111]. In particular, Quiròs et al. [110] reported how silver and copper NPs supported in sepiolite and silica act as reservoirs able to affect microorganism germination and growth, and to reduce fungal metabolic activity.

Table 1 reports a summary with some representative studies dealing with electrospun antimicrobial fibers embedding metal nanoparticles.

Table 1. Some representative studies where electrospun antibacterial nanofibers incorporate metal nanoparticles.

\begin{tabular}{ccc}
\hline Antibacterial Agent & Electrospun Polymer Composite & References \\
\hline CuNPs, CuO NPs & Copper salt + PVP & {$[92]$} \\
& Commercial CuO + PHBV & {$[109]$} \\
& Supported copper salt + CA & {$[110]$} \\
& Cu/CuOx + PAN & {$[103,104,111]$} \\
& Copper salt + PVA & {$[100,101]$} \\
& Copper salt + CMC & {$[107]$} \\
& Copper salt + PVDF & {$[112]$} \\
& Copper salt + PU & {$[113,114]$} \\
\hline AgNPs & Silver salt + PVP & {$[92,93]$} \\
& Supported silver salt + CA & {$[105,110]$} \\
& Silver salt + PAN & {$[108]$} \\
& Silver salt + PVA & {$[94-99]$} \\
\hline Other Me/Me oxides NPs & Copper salt + zinc salt + PVA & {$[102]$} \\
& Zinc salt + CMC & {$[107]$} \\
& Iron salt + CMC & {$[107]$} \\
\hline
\end{tabular}

No matter the preparation method, all the above mentioned composite electrospun nanofibers have been proved to exert good antibacterial properties against many Gram-positive $[70,92,97,99,102-108,113,114]$ and Gram-negative $[70,92,97,99,102,103,105-108,113,114]$ species, as well as antifungal effect [70,108-110]. The detailed analysis on the antibacterial mechanisms involved and the overview on the different antimicrobial tests is beyond the aim of this review; nevertheless, the readers interested in the topic can refer to [115-120].

\section{Conclusions}

In the last decades, great advances have been achieved in the understanding of the electrospinning process, in terms of instrumental development and perspective applications. As a result, it is now possible to easily produce uniform nanofibers from most synthetic polymers and many natural polymers in the lab scale and also for industrial needs. Moreover, numerous biocides have been successfully incorporated into nanofibers to obtain electrospun mats potentially used as medical implants, scaffolds, wound dressings, textiles, or as filter media. Among others, different inorganic nanomaterials composed of transition metals were considered, thanks to their wide range of biocidal activity and because their ions are well tolerated by human beings at concentration levels that are effective towards several microorganisms.

Despite the significant advances, several issues still need to be further addressed in antibacterial nanofibers, mainly related to the controlled release of the antibacterial agents from the nanofibers.

With this in mind, we believe that the combination of metal nanoparticles with innovative polymer synthesis and/or processing technologies, such as the electrospinning technique, affording a high level of morphological and composition control over the resulting material, will represent a proper solution for a further step in the diffusion and exploitation of these agents. 
In the last year, several engineering fields have benefited from the introduction of additive manufacturing technologies and, most recently, a growing tendency to the convergence of different processing techniques into a single, computer-aided manufacturing technology has been reported. It is an opinion of the Authors that this scenario could also affect the field of antimicrobial materials, enabling the large scale fabrication of complex-shaped structures with tailored properties.

Author Contributions: Each of the authors has equally contributed to the writing of the paper.

Funding: This research received no external funding

Conflicts of Interest: "The authors declare no conflict of interest."

\section{References}

1. Huang, Z.M.; Zhang, Y.Z.; Kotaki, M.; Ramakrishna, S. A review on polymer nanofibers by electrospinning and their applications in nanocomposites. Compos. Sci. Technol. 2003, 63, 2223-2253. [CrossRef]

2. Xue, J.; Xie, J.; Liu, W.; Xia, Y. Electrospun nanofibers: New concepts, materials, and applications. Acc. Chem. Res. 2017, 50, 1976-1987. [CrossRef] [PubMed]

3. Cooley, J.F. Apparatus for Electrically Dispersing Fluids. U.S. Patent 692,631A, 6 October 1899.

4. Greiner, A.; Wendorff, J.H. Electrospinning: A fascinating method for the preparation of ultrathin fibers. Angew. Chem. Int. Ed. 2007, 46, 5670-5703. [CrossRef] [PubMed]

5. Frenot, A.; Chronakis, I.S. Polymer nanofibers assembled by electrospinning. Curr. Opin. Colloid Interface Sci. 2003, 8, 64-75. [CrossRef]

6. Anton, F. Artificial Thread and Method of Producing Same. U.S. Patent No. 2,187,306, 28 July 1937.

7. Anton, F. Process and Apparatus for Preparing Artificial Threads. U.S. Patent 1,975,504, 2 October 1934.

8. Srinivasan, G.; Reneker, D.H. Structure and morphology of small diameter electrospun aramid fibers. Polym. Int. 1995, 36, 195-201. [CrossRef]

9. Doshi, J.; Reneker, D.H. Electrospinning process and applications of electrospun fibers. J. Electrostat. 1995, 35, 151-160. [CrossRef]

10. Taylor, G. Electrically Driven Jets. Proc. R. Soc. Lond. A Math. Phys. Eng. Sci. 1969, 313, 453-475. [CrossRef]

11. Taylor, G. Disintegration of Water Drops in an Electric Field. Proc. R. Soc. Lond. A Math. Phys. Eng. Sci. 1964, 280, 383-397. [CrossRef]

12. Reneker, D.H.; Yarin, A.L.; Fong, H.; Koombhongse, S. Bending instability of electrically charged liquid jets of polymer solutions in electrospinning. J. Appl. Phys. 2000, 87, 4531-4547. [CrossRef]

13. Guerrero, J.; Rivero, J.; Gundabala, V.R.; Perez-Saborid, M.; Fernandez-Nieves, A. Whipping of electrified liquid jets. Proc. Natl. Acad. Sci. USA 2014, 111, 13763-13767. [CrossRef] [PubMed]

14. Ramakrishna, S.; Fujihara, K.; Teo, W.-E.; Lim, T.-C.; Ma, Z. An Introduction to Electrospinning and Nanofibers; World Scientific Publishing: Singapore, 2005; ISBN 981-256-415-2, 981-256-454-3.

15. Seyedmahmoud, R.; Rainer, A.; Mozetic, P.; Maria Giannitelli, S.; Trombetta, M.; Traversa, E.; Rinaldi, A. A primer of statistical methods for correlating parameters and properties of electrospun poly (L-lactide) scaffolds for tissue engineering-PART 1: Design of experiments. J. Biomed. Mater. Res. A 2015, 103, 91-102. [CrossRef] [PubMed]

16. Seyedmahmoud, R.; Mozetic, P.; Rainer, A.; Giannitelli, S.M.; Basoli, F.; Trombetta, M.; Rinaldi, A. A primer of statistical methods for correlating parameters and properties of electrospun poly (l-lactide) scaffolds for tissue engineering-PART 2: Regression. J. Biomed. Mater. Res. A 2015, 103, 103-114. [CrossRef] [PubMed]

17. Zander, N.E. Hierarchically structured electrospun fibers. Polymers 2013, 5, 19-44. [CrossRef]

18. Boland, E.D.; Wnek, G.E.; Simpson, D.G.; Pawlowski, K.J.; Bowlin, G.L. Tailoring tissue engineering scaffolds using electrostatic processing techniques: A study of poly (glycolic acid) electrospinning. J. Macromol. Sci. A 2001, 38, 1231-1243. [CrossRef]

19. Matthews, J.A.; Wnek, G.E.; Simpson, D.G.; Bowlin, G.L. Electrospinning of collagen nanofibers. Biomacromolecules 2002, 3, 232-238. [CrossRef] [PubMed]

20. Li, D.; Wang, Y.; Xia, Y. Electrospinning of polymeric and ceramic nanofibers as uniaxially aligned arrays. Nano Lett. 2003, 3, 1167-1171. [CrossRef]

21. Li, D.; Wang, Y.; Xia, Y. Electrospinning nanofibers as uniaxially aligned arrays and layer-by-layer stacked films. Adv. Mater. 2004, 16, 361-366. [CrossRef] 
22. Theron, A.; Zussman, E.; Yarin, A.L. Electrostatic field-assisted alignment of electrospun nanofibres. Nanotechnology 2001, 12, 384. [CrossRef]

23. Wang, Y.; Wang, G.; Chen, L.; Li, H.; Yin, T.; Wang, B.; Yu, Q. Electrospun nanofiber meshes with tailored architectures and patterns as potential tissue-engineering scaffolds. Biofabrication 2009, 1, 015001. [CrossRef] [PubMed]

24. Sun, Z.; Zussman, E.; Yarin, A.L.; Wendorff, J.H.; Greiner, A. Compound core-shell polymer nanofibers by co-electrospinning. Adv. Mater. 2003, 15, 1929-1932. [CrossRef]

25. Khalf, A.; Madihally, S.V. Recent advances in multiaxial electrospinning for drug delivery. Eur. J. Pharm. Biopharm. 2017, 112, 1-17. [CrossRef] [PubMed]

26. Liu, Y.; He, J.H.; Xu, L.; Yu, J.Y. The principle of bubble electrospinning and its experimental verification. J. Polym. Eng. 2008, 28, 55-66. [CrossRef]

27. He, J.H.; Liu, Y. Control of bubble size and bubble number in bubble electrospinning. Comput. Math. Appl. 2012, 64, 1033-1035. [CrossRef]

28. Son, Y.J.; Kim, W.J.; Yoo, H.S. Therapeutic applications of electrospun nanofibers for drug delivery systems. Arch. Pharm. Res. 2014, 37, 69-78. [CrossRef] [PubMed]

29. Zamani, M.; Prabhakaran, M.P.; Ramakrishna, S. Advances in drug delivery via electrospun and electrosprayed nanomaterials. Int. J. Nanomed. 2013, 8, 2997. [CrossRef]

30. Li, H.; Liu, K.; Sang, Q.; Williams, G.R.; Wu, J.; Wang, H.; Zhu, L.M. A thermosensitive drug delivery system prepared by blend electrospinning. Colloid Surf. B 2017, 159, 277-283. [CrossRef] [PubMed]

31. Suja, P.S.; Reshmi, C.R.; Sagitha, P.; Sujith, A. Electrospun nanofibrous membranes for water purification. Polym. Rev. 2017, 57, 467-504. [CrossRef]

32. Liao, Y.; Loh, C.H.; Tian, M.; Wang, R.; Fane, A.G. Progress in electrospun polymeric nanofibrous membranes for water treatment: Fabrication, modification and applications. Prog. Polym. Sci. 2017, 77, 69-94. [CrossRef]

33. Cavaliere, S. (Ed.) Electrospinning for Advanced Energy and Environmental Applications; CRC Press: Boca Raton, FL, USA, 2017.

34. Li, Z.; Zhang, J.W.; Yu, L.G.; Zhang, J.W. Electrospun porous nanofibers for electrochemical energy storage. J. Mater. Sci. 2017, 52, 6173-6195. [CrossRef]

35. Sapountzi, E.; Braiek, M.; Chateaux, J.F.; Jaffrezic-Renault, N.; Lagarde, F. Recent Advances in Electrospun Nanofiber Interfaces for Biosensing Devices. Sensors 2017, 17, 1887. [CrossRef] [PubMed]

36. Ding, B.; Wang, M.; Yu, J.; Sun, G. Gas sensors based on electrospun nanofibers. Sensors 2009, 9, 1609-1624. [CrossRef] [PubMed]

37. Ding, B.; Wang, M.; Wang, X.; Yu, J.; Sun, G. Electrospun nanomaterials for ultrasensitive sensors. Mater. Today 2010, 13, 16-27. [CrossRef]

38. Luzio, A.; Canesi, E.V.; Bertarelli, C.; Caironi, M. Electrospun polymer fibers for electronic applications. Materials 2014, 7, 906-947. [CrossRef] [PubMed]

39. Zewe, J.W.; Steach, J.K.; Olesik, S.V. Electrospun fibers for solid-phase microextraction. Anal. Chem. 2010, 82, 5341-5348. [CrossRef] [PubMed]

40. Moheman, A.; Alam, M.S.; Mohammad, A. Recent trends in electrospinning of polymer nanofibers and their applications in ultra thin layer chromatography. Adv. Colloid Interface Sci. 2016, 229, 1-24. [CrossRef] [PubMed]

41. Cho, D.; Matlock-Colangelo, L.; Xiang, C.; Asiello, P.J.; Baeumner, A.J.; Frey, M.W. Electrospun nanofibers for microfluidic analytical systems. Polymer 2011, 52, 3413-3421. [CrossRef]

42. Wallin, P.; Zandén, C.; Carlberg, B.; Hellström Erkenstam, N.; Liu, J.; Gold, J. A method to integrate patterned electrospun fibers with microfluidic systems to generate complex microenvironments for cell culture applications. Biomicrofluidics 2012, 6, 024131. [CrossRef] [PubMed]

43. Giannitelli, S.M.; Costantini, M.; Basoli, F.; Trombetta, M.; Rainer, A. Electrospinning and microfluidics: An integrated approach for tissue engineering and cancer. In Electrofluidodynamic Technologies (EFDTs) for Biomaterials and Medical Devices; Woodhead Publishing: Sawston, UK, 2018; pp. 139-155. [CrossRef]

44. Cioffi, N.; Rai, M. Nano-Antimicrobials: Progress and Prospects, 1st ed.; Springer: Berlin, Germany, $2012 ;$ p. 504. ISBN 978-3-642-24427-8.

45. World Health Organization. Available online: http://www.who.int/antimicrobial-resistance/en/ (accessed on 31 July 2018). 
46. Baptista, P.V.; McCusker, M.P.; Carvalho, A.; Ferreira, D.A.; Mohan, N.M.; Martins, M.; Fernandes, A.R. Nano-Strategies to Fight Multidrug Resistant Bacteria-“A Battle of the Titans”. Front. Microbiol. 2018, 9, 1441. [CrossRef]

47. Natan, M.; Banin, E. From Nano to Micro: Using nanotechnology to combat microorganisms and their multidrug resistance. FEMS Microbiol. Rev. 2017, 41, 302-322. [CrossRef] [PubMed]

48. Sportelli, M.C.; Picca, R.A.; Cioffi, N. Recent advances in the synthesis and characterization of nano-antimicrobials. TRAC-Trend Anal. Chem. 2016, 84, 131-138. [CrossRef]

49. PEN. The Project on Emerging Nanotechnologies. Available online: http://www.nanotechproject.org/ (accessed on 31 July 2018).

50. Hochmannova, L.; Vytrasova, J. Photocatalytic and antimicrobial effects of interior paints. Prog. Org. Coat. 2010, 67, 1-5. [CrossRef]

51. Eleftheriadou, M.; Pyrgiotakis, G.; Demokritou, P. Nanotechnology to the rescue: Using nano-enabled approaches in microbiological food safety and quality. Curr. Opin. Biotechnol. 2017, 44, 87-93. [CrossRef] [PubMed]

52. Kaygusuz, M. Application of Antimicrobial Nano-Materials on Leather: A Review. J. Soc. Leather Technol. Chem. 2017, 101, 173-178.

53. Cheng, L.; Zhang, K.; Zhang, N.; Melo, M.A.S.; Weir, M.D.; Zhou, X.D.; Xu, H.H.K. Developing a new generation of antimicrobial and bioactive dental resins. J. Dent. Res. 2017, 96, 855-863. [CrossRef] [PubMed]

54. Windler, L.; Height, M.; Nowack, B. Comparative evaluation of antimicrobials for textile applications. Environ. Int. 2013, 53, 62-73. [CrossRef] [PubMed]

55. Pachuau, L. Recent developments in novel drug delivery systems for wound healing. Expert Opin. Drug Deliv. 2015, 12, 1895-1909. [CrossRef] [PubMed]

56. Llorens, A.; Lloret, E.; Picouet, P.A.; Trbojevich, R.; Fernandez, A. Metallic-based micro and nanocomposites in food contact materials and active food packaging. Trends Food Sci. Technol. 2012, 24, 19-29. [CrossRef]

57. Le Ouay, B.; Stellacci, F. Antibacterial activity of silver nanoparticles: A surface science insight. Nano Today 2015, 10, 339-354. [CrossRef]

58. Ivask, A.; Juganson, K.; Bondarenko, O.; Mortimer, M.; Aruoja, V.; Kasemets, K.; Kahru, A. Mechanisms of toxic action of $\mathrm{Ag}, \mathrm{ZnO}$ and $\mathrm{CuO}$ nanoparticles to selected ecotoxicological test organisms and mammalian cells in vitro: A comparative review. Nanotoxicology 2014, 8, 57-71. [CrossRef] [PubMed]

59. Cioffi, N.; Torsi, L.; Ditaranto, N.; Sabbatini, L.; Zambonin, P.G.; Tantillo, G.; Ghibelli, L.; D'Alessio, M.; Bleve-Zacheo, T.; Traversa, E. Antifungal activity of polymer-based copper nanocomposite coatings. Appl. Phys. Lett. 2004, 85, 2417-2419. [CrossRef]

60. Cioffi, N.; Torsi, L.; Ditaranto, N.; Tantillo, G.; Ghibelli, L.; Sabbatini, L.; Bleve-Zacheo, T.; D'Alessio, M.; Zambonin, P.G.; Traversa, E. Copper nanoparticle/polymer composites with antifungal and bacteriostatic properties. Chem. Mater. 2005, 17, 5255-5262. [CrossRef]

61. Sportelli, M.C.; Tütüncü, E.; Picca, R.A.; Valentini, M.; Valentini, A.; Kranz, C.; Mizaikoff, B.; Barth, H.; Cioffi, N. Inhibiting P. fluorescens biofilms with fluoropolymer-embedded silver nanoparticles: An in-situ spectroscopic study. Sci. Rep. 2017, 7, 1-13. [CrossRef] [PubMed]

62. Picca, R.A.; Paladini, F.; Sportelli, M.C.; Pollini, M.; Giannossa, L.C.; Di Franco, C.; Mangone, A.; Valentini, A.; Cioffi, N. Combined approach for the development of efficient and safe nanoantimicrobials: The case of nanosilver-modified polyurethane foams. ACS Biomater. Sci. Eng. 2016, 3, 1417-1425. [CrossRef]

63. Reddy, K.V.R.; Yedery, R.D.; Aranha, C. Antimicrobial peptides: Premises and promises. Int. J. Antimicrob. Agents 2004, 24, 536-547. [CrossRef] [PubMed]

64. Al-Badri, Z.M.; Som, A.; Lyon, S.; Nelson, C.F.; Nüsslein, K.; Tew, G.N. Investigating the effect of increasing charge density on the hemolytic activity of synthetic antimicrobial polymers. Biomacromolecules 2008, 9, 2805-2810. [CrossRef] [PubMed]

65. Song, A.; Walker, S.G.; Parker, K.A.; Sampson, N.S. Antibacterial studies of cationic polymers with alternating, random, and uniform backbones. ACS Chem. Biol. 2011, 6, 590-599. [CrossRef] [PubMed]

66. Brand, A.M.; De Kwaadsteniet, M.; Dicks, L.M.T. The ability of nisin F to control Staphylococcus aureus infection in the peritoneal cavity, as studied in mice. Lett. Appl. Microbiol. 2010, 51, 645-649. [CrossRef] [PubMed]

67. Perron, G.G.; Zasloff, M.; Bell, G. Experimental evolution of resistance to an antimicrobial peptide. Proc. R. Soc. Lond. B Biol. 2006, 273, 251-256. [CrossRef] [PubMed] 
68. Arkoun, M.; Daigle, F.; Holley, R.A.; Heuzey, M.C.; Ajji, A. Chitosan-based nanofibers as bioactive meat packaging materials. Packag. Technol. Sci. 2018, 31, 185-195. [CrossRef]

69. Vineis, C.; Varesano, A. Natural polymer-based electrospun fibers for antibacterial uses. In Electrofluidodynamic Technologies (EFDTs) for Biomaterials and Medical Devices; Woodhead Publishing: Sawston, UK, 2018; pp. 275-294. [CrossRef]

70. Bshena, O.; Heunis, T.D.; Dicks, L.M.; Klumperman, B. Antimicrobial fibers: Therapeutic possibilities and recent advances. Future Med. Chem. 2011, 3, 1821-1847. [CrossRef] [PubMed]

71. Gao, Y.; Bach Truong, Y.; Zhu, Y.; Louis Kyratzis, I. Electrospun antibacterial nanofibers: Production, activity, and in vivo applications. J. Appl. Polym. Sci. 2014, 131. [CrossRef]

72. Narayanan, G.; Gupta, B.S.; Tonelli, A.E. Poly ( $\varepsilon$-caprolactone) nanowebs functionalized with $\alpha$-and $\gamma$-cyclodextrins. Biomacromolecules 2014, 15, 4122-4133. [CrossRef] [PubMed]

73. Aytac, Z.; Yildiz, Z.I.; Kayaci-Senirmak, F.; San Keskin, N.O.; Kusku, S.I.; Durgun, E.; Uyar, T. Fast-dissolving, prolonged release, and antibacterial cyclodextrin/limonene-inclusion complex nanofibrous webs via polymer-free electrospinning. J. Agric. Food Chem. 2016, 64, 7325-7334. [CrossRef] [PubMed]

74. Celebioglu, A.; Umu, O.C.; Tekinay, T.; Uyar, T. Antibacterial electrospun nanofibers from triclosan/cyclodextrin inclusion complexes. Colloid Surf. B 2014, 116, 612-619. [CrossRef] [PubMed]

75. Kayaci, F.; Umu, O.C.; Tekinay, T.; Uyar, T. Antibacterial electrospun poly (lactic acid) (PLA) nanofibrous webs incorporating triclosan/cyclodextrin inclusion complexes. J. Agric. Food Chem. 2013, 61, 3901-3908. [CrossRef] [PubMed]

76. Barrientos, I.J.H.; Paladino, E.; Brozio, S.; Passarelli, M.K.; Moug, S.; Black, R.A.; Lamprou, D.A. Fabrication and characterisation of drug-loaded electrospun polymeric nanofibers for controlled release in hernia repair. Int. J. Pharm. 2017, 517, 329-337. [CrossRef] [PubMed]

77. Chou, S.F.; Woodrow, K.A. Relationships between mechanical properties and drug release from electrospun fibers of PCL and PLGA blends. J. Mech. Behav. Biomed. 2017, 65, 724-733. [CrossRef] [PubMed]

78. Torres-Giner, S.; Gimeno-Alcaniz, J.V.; Ocio, M.J.; Lagaron, J.M. Comparative performance of electrospun collagen nanofibers cross-linked by means of different methods. ACS Appl. Mater. Interfaces 2008, 1, 218-223. [CrossRef] [PubMed]

79. Sohrabi, A.; Shaibani, P.M.; Etayash, H.; Kaur, K.; Thundat, T. Sustained drug release and antibacterial activity of ampicillin incorporated poly (methyl methacrylate)-nylon6 core/shell nanofibers. Polymer 2013, 54, 2699-2705. [CrossRef]

80. Su, Y.; Li, X.; Wang, H.; He, C.; Mo, X. Fabrication and characterization of biodegradable nanofibrous mats by mix and coaxial electrospinning. J. Mater. Sci. Mater. Med. 2009, 20, 2285. [CrossRef] [PubMed]

81. Balakrishnan, P.; Gardella, L.; Forouharshad, M.; Pellegrino, T.; Monticelli, O. Star poly ( $\varepsilon$-caprolactone)-based electrospun fibers as biocompatible scaffold for doxorubicin with prolonged drug release activity. Colloid Surf. B 2018, 161, 488-496. [CrossRef] [PubMed]

82. Wang, S.; Zheng, F.; Huang, Y.; Fang, Y.; Shen, M.; Zhu, M.; Shi, X. Encapsulation of amoxicillin within laponite-doped poly (lactic-co-glycolic acid) nanofibers: Preparation, characterization, and antibacterial activity. ACS Appl. Mater. Interfaces 2012, 4, 6393-6401. [CrossRef] [PubMed]

83. Zheng, F.; Wang, S.; Wen, S.; Shen, M.; Zhu, M.; Shi, X. Characterization and antibacterial activity of amoxicillin-loaded electrospun nano-hydroxyapatite/poly (lactic-co-glycolic acid) composite nanofibers. Biomaterials 2013, 34, 1402-1412. [CrossRef] [PubMed]

84. Timofeeva, L.; Kleshcheva, N. Antimicrobial polymers: Mechanism of action, factors of activity, and applications. Appl. Microbiol. Biotechnol. 2011, 89, 475-492. [CrossRef] [PubMed]

85. Isquith, A.J.; Abbott, E.A.; Walters, P.A. Surface-bonded antimicrobial activity of an organosilicon quaternary ammonium chloride. Appl. Microbiol. 1972, 24, 859-863. [PubMed]

86. Walters, P.A.; Abbott, E.A.; Isquith, A.J. Algicidal activity of a surface-bonded organosilicon quaternary ammonium chloride. Appl. Microbiol. 1973, 25, 253-256. [PubMed]

87. Isquith, A.J.; McCollum, C.J. Surface kinetic test method for determining rate of kill by an antimicrobial solid. Appl. Environ. Microb. 1978, 36, 700-704.

88. Nakagawa, Y.; Hayashi, H.; Tawaratani, T.; Kourai, H.; Horie, T.; Shibasaki, I. Disinfection of water with quaternary ammonium salts insolubilized on a porous glass surface. Appl. Environ. Microb. 1984, 47, 513-518.

89. Jaeger, W.; Bohrisch, J.; Laschewsky, A. Synthetic polymers with quaternary nitrogen atoms—Synthesis and structure of the most used type of cationic polyelectrolytes. Prog. Polym. Sci. 2010, 35, 511-577. [CrossRef] 
90. Koqiso, M.; Yoshida, K.; Yase, K.; Shimizu, T. One-dimensional organization of copper nanoparticles by chemical reduction of lipid-copper hybrid nanofibers. Chem. Commun. 2002, 10, 2492. [CrossRef]

91. Chernousova, S.; Epple, M. Silver as antibacterial agent: Ion, nanoparticle, and metal. Angew. Chem. Int. Ed. 2013, 52, 1636-1653. [CrossRef] [PubMed]

92. Quirós, J.; Borges, J.P.; Boltes, K.; Rodea-Palomares, I.; Rosal, R. Antimicrobial electrospun silver-, copper-and zinc-doped polyvinylpyrrolidone nanofibers. J. Hazard. Mater. 2015, 299, 298-305. [CrossRef] [PubMed]

93. SCOPUS Database. Available online: http:/ / www.scopus.com (accessed on 31 July 2018).

94. Jatoi, A.W.; Jo, Y.K.; Lee, H.; Oh, S.G.; Hwang, D.S.; Khatri, Z.; Kim, I.S. Antibacterial efficacy of poly (vinyl alcohol) composite nanofibers embedded with silver-anchored silica nanoparticles. J. Biomed. Mater. Res. $B$ 2018, 106, 1121-1128. [CrossRef] [PubMed]

95. Zhu, M.; Hua, D.; Pan, H.; Wang, F.; Manshian, B.; Soenen, S.J.; Huang, C. Green electrospun and crosslinked poly (vinyl alcohol)/poly (acrylic acid) composite membranes for antibacterial effective air filtration. J. Colloid Interface Sci. 2018, 511, 411-423. [CrossRef] [PubMed]

96. Jin, W.J.; Jeon, H.J.; Kim, J.H.; Youk, J.H. A study on the preparation of poly (vinyl alcohol) nanofibers containing silver nanoparticles. Synth. Met. 2007, 157, 454-459. [CrossRef]

97. Celebioglu, A.; Aytac, Z.; Umu, O.C.; Dana, A.; Tekinay, T.; Uyar, T. One-step synthesis of size-tunable Ag nanoparticles incorporated in electrospun PVA/cyclodextrin nanofibers. Carbohyd. Polym. 2014, 99, 808-816. [CrossRef] [PubMed]

98. Chun, J.Y.; Kang, H.K.; Jeong, L.; Kang, Y.O.; Oh, J.E.; Yeo, I.S.; Min, B.M. Epidermal cellular response to poly (vinyl alcohol) nanofibers containing silver nanoparticles. Colloid Surf. B 2010, 78, 334-342. [CrossRef] [PubMed]

99. Hong, K.H.; Park, J.L.; Sul, I.H.; Youk, J.H.; Kang, T.J. Preparation of antimicrobial poly (vinyl alcohol) nanofibers containing silver nanoparticles. J. Polym. Sci. Polym. Phys. 2006, 44, 2468-2474. [CrossRef]

100. Li, Z.; Huang, H.; Wang, C. Electrostatic forces induce poly (vinyl alcohol)-protected copper nanoparticles to form copper/poly (vinyl alcohol) nanocables via electrospinning. Macromol. Rapid Commun. 2006, 27, 152-155. [CrossRef]

101. Khalil, A.; Jouiad, M.; Khraisheh, M.; Hashaikeh, R. Facile synthesis of copper oxide nanoparticles via electrospinning. J. Nanomater. 2014, 2014, 80. [CrossRef]

102. Malwal, D.; Gopinath, P. Efficient adsorption and antibacterial properties of electrospun CuO-ZnO composite nanofibers for water remediation. J. Hazard. Mater. 2017, 321, 611-621. [CrossRef] [PubMed]

103. Xiao, Y.; Cao, Y.; Xin, B.; Liu, Y.; Chen, Z.; Lin, L.; Sun, Y. Fabrication and characterization of electrospun cellulose/polyacrylonitrile nanofibers with $\mathrm{Cu}$ (II) ions. Cellulose 2018, 25, 2955-2963. [CrossRef]

104. Zhang, C.; Li, C.; Bai, J.; Wang, J.; Li, H. Synthesis, characterization, and antibacterial activity of Cu NPs embedded electrospun composite nanofibers. Colloid Polym. Sci. 2015, 293, 2525-2530. [CrossRef]

105. Son, W.K.; Youk, J.H.; Lee, T.S.; Park, W.H. Preparation of antimicrobial ultrafine cellulose acetate fibers with silver nanoparticles. Macromol. Rapid Commun. 2004, 25, 1632-1637. [CrossRef]

106. Shalaby, T.; Hamad, H.; Ibrahim, E.; Mahmoud, O.; Al-Oufy, A. Electrospun nanofibers hybrid composites membranes for highly efficient antibacterial activity. Ecotoxicol. Environ. Saf. 2018, 162, 354-364. [CrossRef] [PubMed]

107. Gouda, M.; Aljaafari, A.; Al-Omair, M.A. Functional electrospun cellulosic nanofiber mats for antibacterial bandages. Fibers Polym. 2017, 18, 2379-2386. [CrossRef]

108. Shi, Y.; Li, Y.; Zhang, J.; Yu, Z.; Yang, D. Electrospun polyacrylonitrile nanofibers loaded with silver nanoparticles by silver mirror reaction. Mater. Sci. Eng. C 2015, 51, 346-355. [CrossRef] [PubMed]

109. Castro Mayorga, J.L.; Fabra Rovira, M.J.; Cabedo Mas, L.; Sánchez Moragas, G.; Lagarón Cabello, J.M. Antimicrobial nanocomposites and electrospun coatings based on poly (3-hydroxybutyrateco-3-hydroxyvalerate) and copper oxide nanoparticles for active packaging and coating applications. J. Appl. Polym. Sci. 2018, 135, 45673. [CrossRef]

110. Quirós, J.; Gonzalo, S.; Jalvo, B.; Boltes, K.; Perdigón-Melón, J.A.; Rosal, R. Electrospun cellulose acetate composites containing supported metal nanoparticles for antifungal membranes. Sci. Total Environ. 2016, 563, 912-920. [CrossRef] [PubMed]

111. Bajaj, B.; Joh, H.I.; Jo, S.M.; Park, J.H.; Yi, K.B.; Lee, S. Enhanced reactive H2S adsorption using carbon nanofibers supported with $\mathrm{Cu} / \mathrm{CuxO}$ nanoparticles. Appl. Surf. Sci. 2018, 429, 253-257. [CrossRef] 
112. Santos, J.P.F.; da Silva, A.B.; Arjmand, M.; Sundararaj, U.; Bretas, R.E.S. Nanofibers of poly (vinylidene fluoride)/copper nanowire: Microstructural analysis and dielectric behavior. Eur. Polym. J. 2018, 101, 46-55. [CrossRef]

113. Sheikh, F.A.; Kanjwal, M.A.; Saran, S.; Chung, W.J.; Kim, H. Polyurethane nanofibers containing copper nanoparticles as future materials. Appl. Surf. Sci. 2011, 257, 3020-3026. [CrossRef]

114. Ahmad, Z.; Vargas-Reus, M.A.; Bakhshi, R.; Ryan, F.; Ren, G.G.; Oktar, F.; Allaker, R.P. Antimicrobial properties of electrically formed elastomeric polyurethane-copper oxide nanocomposites for medical and dental applications. In Methods in Enzymology; Academic Press: Cambridge, CA, USA, 2012; Volume 509, pp. 87-99.

115. Pareek, V.; Gupta, R.; Panwar, J. Do physico-chemical properties of silver nanoparticles decide their interaction with biological media and bactericidal action? A review. Mater. Sci. Eng. C 2018, 90, 739-749. [CrossRef] [PubMed]

116. Slavin, Y.N.; Asnis, J.; Häfeli, U.O.; Bach, H. Metal nanoparticles: Understanding the mechanisms behind antibacterial activity. J. Nanobiotechnol. 2017, 15, 65-84. [CrossRef] [PubMed]

117. Zhang, X.F.; Shen, W.; Gurunathan, S. Silver nanoparticle-mediated cellular responses in various cell lines: An in vitro model. Int. J. Mol. Sci. 2016, 17, 1603. [CrossRef] [PubMed]

118. Beyth, N.; Houri-Haddad, Y.; Domb, A.; Khan, W.; Hazan, R. Alternative antimicrobial approach: Nano-antimicrobial materials. Evid. Based Complement. Altern. Med. 2015, 2015, 1-16. [CrossRef] [PubMed]

119. Cavassin, E.D.; de Figueiredo, L.F.P.; Otoch, J.P.; Seckler, M.M.; de Oliveira, R.A.; Franco, F.F.; Costa, S.F. Comparison of methods to detect the in vitro activity of silver nanoparticles (AgNP) against multidrug resistant bacteria. J. Nanobiotechnol. 2015, 13, 64. [CrossRef] [PubMed]

120. Bankier, C.; Cheong, Y.; Mahalingam, S.; Edirisinghe, M.; Ren, G.; Cloutman-Green, E.; Ciric, L. A comparison of methods to assess the antimicrobial activity of nanoparticle combinations on bacterial cells. PLOS ONE 2018, 13, e0192093. [CrossRef] [PubMed]

(C) 2018 by the authors. Licensee MDPI, Basel, Switzerland. This article is an open access article distributed under the terms and conditions of the Creative Commons Attribution (CC BY) license (http:/ / creativecommons.org/licenses/by/4.0/). 